\title{
Biochemical Study of Oxidative Stress Markers in the Liver, Kidney and Heart of High Fat Diet Induced Obesity in Rats
}

Saad A Noeman*, Hala E Hamooda and Amal A Baalash

\begin{abstract}
Background: Obesity has become a leading global health problem owing to its strong association with a high incidence of diseases.

Aim: To induce rat obesity using high fat diet (HFD) and to estimate oxidative stress markers in their liver, heart and kidney tissues in order to shed the light on the effect of obesity on these organs.

Materials and methods: Sixty white albino rats weighing 150-200 $\mathrm{g}$ were randomly divided into two equal groups; group I: received high fat diet for 16 weeks, and group II (control group): received only normal diet (rat chow) for 16 weeks. Blood samples were taken for measurement of lipid profile, tissue samples from liver, heart and kidney were taken for determination of malondialdehyde (MDA), protein carbonyl (PCO), reduced glutathione (GSH) levels, and the activities of glutathione S- transferase (GST) glutathione peroxidase (GPx), catalase (CAT) and paraoxonase1 (PON1) enzymes.

Results: Data showed that feeding HFD diet significantly increased final body weight and induced a state of dyslipideamia. Also our results showed a significant increase MDA and PCO levels in the hepatic, heart and renal tissues of obese rats, as well as a significant decrease in the activity of GST, GPx and PON 1 enzymes. On the other hand CAT enzyme activity showed significant decrease only in renal tissues of obese rats with non significant difference in hepatic and heart tissues. GSH levels showed significant decrease in both renal and hepatic tissues of obese animals and significant increase in their heart tissues. Correlation studies in obese animals showed a negative correlation between MDA and PCO tissue levels and the activities of GPx, GST and PON1 in all tissues and also with CAT enzyme activity in renal tissues. Also a negative correlation was detected between MDA \& PCO tissues levels and GSH levels in both hepatic and renal tissues. While positive correlation was found between them and GSH levels in heart tissues.

Conclusion: High fat diet-induced obesity is accompanied by increased hepatic, heart, and renal tissues oxidative stress, which is characterized by reduction in the antioxidant enzymes activities and glutathione levels, that correlate with the increase in MDA and PCO levels in most tissues. This may probably contribute to the additional progression of obesity related problems.
\end{abstract}

\section{Introduction}

Obesity is a pathological condition in which excess body fat has accumulated to the extent that it may have an adverse effect on health, leading to reduced life expectancy and/or increased health problems [1]. The induction of obesity may be performed in animals by

\footnotetext{
* Correspondence: nooman1234@hotmail.com

Medical Biochemistry Department, Faculty of Medicine, Tanta University, Egypt
}

\section{Biomed Central}

(c) 2011 Noeman et al; licensee BioMed Central Ltd. This is an Open Access article distributed under the terms of the Creative Commons Attribution License (http://creativecommons.org/licenses/by/2.0), which permits unrestricted use, distribution, and reproduction in any medium, provided the original work is properly cited. neuroendocrine, dietary or genetic changes [2]. The great similarity and homology between the genomes of rodents and humans make these animal models a major tool to study obesity [2].

Oxidative stress is highly correlated with a wide variety of inflammatory and metabolic disease states, including obesity [3, 4, and 5]. It is highly correlated with cumulative damage in the body done by free radicals inadequately neutralized by antioxidants [6]. It has been 
shown that free radicals may adversely affect cell survival because of membrane damage through the oxidative damage of lipid, protein and irreversible DNA modification [7]. Lipid peroxidation such as thiobarbituric acid reactive substances and hydroperoxides levels as well as markers of protein oxidation such as carbonyl proteins are markers of oxidative damage of ROS [8,9].

Furthermore oxidative damage is aggravated by the decrease in antioxidant enzymes activities such as superoxide dismutase, catalase (CAT), glutathione S-transferase (GST), and glutathione peroxidase (GPx) which acts as a free radical scavengers in conditions associated with oxidative stress [10].

Paraoxonase (PON1) is another antioxidant enzyme closely associated with high-density lipoproteins. It is a calcium-dependent esterase, which detoxifies lipid peroxides, and is widely distributed in many tissues, including the liver, brain, lung, heart, kidneys, small intestine and aorta [11].

Evidence suggests that a clustering of sources of oxidative stress exists in obesity; hyperglycemia, increased tissue lipid levels, inadequate antioxidant defenses, increased rates of free radical formation, and chronic inflammation [12]. Obesity affected many organs in the body such as liver, heart and kidney. Fatty liver and nephropathy are commons complication of obesity [13]. Arthrosclerosis and cardiac complications are more common among obese individuals $[14,15]$.

Therefore the present study was designed to investigate the development of obesity in response to a high fat diet (HFD) and to estimate oxidative stress markers in the liver, heart and kidney in obese rats to shed the light on the effect of obesity on these organs.

\section{Materials and methods}

This study was carried out on 60 white males and females' albino rats, their weight ranged between 150200 g. During the study the animals were kept in wire mesh cages with ad libitum access to water. The room temperature was about $22-24^{\circ} \mathrm{C}$ and the animals were exposed to 12:12 hours light dark cycles. The animals were randomly divided into two equal groups:

Group I: received the high fat diet for 16 weeks.

Group II (control group): received only normal diet ad libitum (rat chow) for 16 weeks. Composition of the experimental diet ( $\mathrm{g} / \mathrm{kg}$ diet) was according to the formula of Kim et al. [16] with some modefications. It included the normal diet for control rats (Fat 5\% [corn oil 5\%], carbohydrates $65 \%$ [corn starch $15 \%$ and sucrose $50 \%$ ], proteins $20.3 \%$ [casein $20 \%$ and DL-Methionine $3 \%$ ], fiber $5 \%$, salt mixture $3.7 \%$, and vitamin mixture $1 \%$ ). The high fat diet contained (fat $46 \%$ [corn oil $25.5 \%$, and beef tallow $20.5 \%$ ], carbohydrates $24 \%$ [corn starch $6 \%$ and sucrose $18 \%$ ], proteins $20.3 \%$ [casein $20 \%$ and DL-Methionine 3\%], fiber 5\%, salt mixture 3.7\%, and vitamin mixture $1 \%$ ).

Normal and HFD constituents were purchased from El-Gomhoria Company, Cairo, Egypt. HFD was preserved at $4^{\circ} \mathrm{C}$ until used. Obesity was induced in 16 weeks.

Our work was carried out in accordance with the guidelines of the Ethical Committee of Medical Research of Faculty of Medicine Tanta University.

\section{Sample collection}

By the end of the experimental period, all rats were sacrificed and blood samples were collected. Sera were separated and stored in aliquots at $-70^{\circ} \mathrm{C}$ till used for estimation of lipid profile including; total cholesterol [17], triglycerides [18], LDL-cholesterol, VLDL [19], and HDL-cholesterol [20], by enzymatic colorimetric methods using commercial kits.

Then the abdomen and the thorax were opened and both liver, kidneys and heart were removed, washed three times in ice cold saline and blotted individually on ash-free filter paper, used for preparation of tissue homogenates for estimation of tissue MDA, PCO, GSH levels and the activity of GST, GPx, CAT and PON1 enzymes.

\section{Preparation of tissue homogenates}

Specimens from each organ were separated into three parts. Each piece was weighted and homogenized separately with a potter- Elvenhjem tissue homogenizer One part was homogenized in phosphate buffer saline (PBS) $50 \mathrm{mM} \mathrm{pH}$ (7.4) for estimation of protein content, GST, CAT enzymes activities and GSH level, the second was homogenized in potassium phosphate buffer $10 \mathrm{mM} \mathrm{pH}$ (7.4) for estimation of MDA, PCO levels and GPx activity, and the third in Tris- $\mathrm{HCl} 100 \mathrm{mM}, \mathrm{pH}$ (8) for estimation of PON1 activity. The crude tissue homogenate was centrifuged at $10,000 \mathrm{rpm}$, for 15 minutes in cold centrifuge, and the resultant supernatant was used for the different estimations. Protein content in tissue homogenate was measured according to the method of Lowry et al. [21].

\section{Chemicals}

Cummene hydroperoxide, 1-chloro-2, 4-dinitrobenzene (CDNB), 5-5-dithiobis-2-nitrobenzoic acid (DTNB) paraoxon and Dinitrophenylhydrazine (DNPH) were obtained from (Sigma chemical Co. St., Louis, MO, USA). Thiobarbituric acid (TBA) and reduced glutathione (GSH) were obtained from Fluka Chemical Co. Trichloroacetic acid (TCA) were obtained from Merk Chemical Co USA. Acetic acid, potassium dichromate, hydrogen peroxide, hydrochloric acid and ethanol were obtained from El-Nasr chemical Co. 
Spectrophotometric determination of tissues MDA, PCO, and GSH levels

MDA

This method depends on the formation of MDA as an end product of lipid peroxidation which reacts with thiobarbituric acid producing thiobarbituric acid reactive substance (TBARS), a pink chromogen, which can be measured spectrophotometrically at $532 \mathrm{~nm}$, an MDA standard was used to construct a standard curve against which readings of the samples were plotted [22].

\section{PCO}

This method depends on the formation of a Schiff base from the reaction of dinitrophenylhydrazine with protein carbonyls to form protein hydrazones which was measured spectrophotometrically. Briefly, after precipitation of protein with an equal volume of $1 \%$ trichloroacetic acid, the pellet was resuspended in $10 \mathrm{mmol} / \mathrm{L} \mathrm{DNPH}$ plus $2 \mathrm{~N} \mathrm{HCl}$, or in $2 \mathrm{~N} \mathrm{HCl}$ as a control blank. Next, after the washing procedure with 1:1 ethanol-ethylacetate, the final palette was dissolved in $6 \mathrm{~mol} / \mathrm{L}$ guanidine. The carbonyl group was determined from the absorbance at $370 \mathrm{~nm}$. The carbonyl content was calculated in terms of $\mathrm{nmol} / \mathrm{mg}$ protein $[23,24]$.

\section{GSH}

The method is based on the reduction of 5,5 dithiobis (2-nitrobenzoic acid) (DTNB) with reduced glutathione (GSH) to produce a yellow compound. The reduced chromogen is directly proportional to GSH concentration and its absorbance can be measured at $405 \mathrm{~nm}$ by using a commercial kit was used (Biodiagnostic, Egypt) [25].

\section{Enzymatic Assays}

Tissues GST enzyme activity: it measures the conjugation of 1-chloro-2,4-dinitro benzene (CDNB) with reduced glutathione that produces a dinitrophenyl thioether which can be detected by spectrophotometer at $340 \mathrm{~nm}$. One unit of GST activity is defined as the amount of enzyme producing $1 \mathrm{mmol}$ of CDNB-GSH conjugate/min under the conditions of the assay according to the method described by Habig et al. [26].

Tissues GPx enzyme activity: it was measured as IU/ gm wet tissue by the reaction between glutathione remaining after the action of GPx and 5, 5-dithiobis-(2nitrobenzoic acid) to form a complex that absorbs maximally at $412 \mathrm{~nm}$. Glutathione peroxidase activity of $1 \mathrm{U} /$ $\mathrm{mg}$ protein was defined as $1 \mu \mathrm{g}$ of GSH consumed/min/ mg protein [27].

Determination of tissues CAT enzyme activity: it assayed by the method of Sinha which based on formation of chromic acetate from dichromate and glacial acetic acid in presence hydrogen peroxide, chromic acetate that produced was measures colorimetrically at 570 $\mathrm{nm}$, one enzyme unit was defined as the amount of enzyme which catalyzed the oxidation of $1 \mu$ mole $\mathrm{H}_{2} \mathrm{O}_{2}$ per minute under assay conditions [28].

Tissues PON1 enzyme activity: PON1 activity towards paraoxon (O,O-diethyl-O-p-nitrophenyl phosphate) was determined by measuring the initial rate of substrate hydrolysis to p- nitrophenol, whose absorbance was monitored at $405 \mathrm{~nm}$ in the assay mixture, A PON1 activity of $1 \mathrm{U} / \mathrm{mg}$ protein was defined as $1 \mu \mathrm{mol} \mathrm{p}$ nitrophenol formed per minute per mg protein [29].

\section{Statistical analysis}

All the statistical analyses were processed using Statistical Program of Social Sciences (SPSS) for windows, version 10.0. Values of the measured parameters were expressed as mean value \pm SD and the difference between the two groups was determined using unpaired student's t-test, and the significance was considered at $\mathrm{p}$ values $<0.05$. Correlation between variables was evaluated using Pearson's correlation coefficient with level of significance $<0.05$.

\section{Results}

By the end of the 16 weeks there was a significant increase in the weight of high fat diet fed rats; (group I) compared to the control (group II), (Figure 1). Also there was significant increase in serum levels of total triglycerides, total cholesterol, LDL-cholesterol and VLDLcholesterol with low level of HDL-cholesterol in obese rats as compared with the control (Table 1).

Our results showed a statistically significant increase in the hepatic tissues levels of MDA and PCO in obese rats when compared to the control group, ( $p<0.05)$. Concerning the antioxidant enzymes activities in obese animals, the present study showed a statistical significant decrease in the activities of hepatic GST, GPx and PON 1 enzymes, and also decrease in hepatic GSH level in obese rats compared to control. Non significant

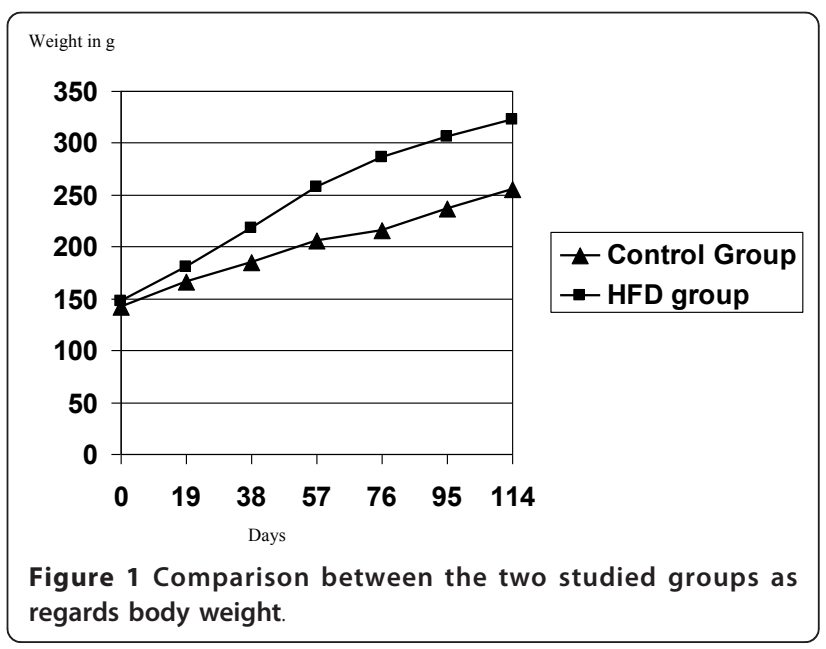


Table 1 Statistical comparison between all studied groups as regards to lipid profile

\begin{tabular}{lccc}
\hline Parameter & $\begin{array}{c}\text { Group I } \\
(\mathbf{n}=\mathbf{3 0})\end{array}$ & $\begin{array}{c}\text { Group II } \\
(\mathbf{n}=\mathbf{3 0})\end{array}$ & $\mathbf{P}$ \\
\hline Total triglycerdies (mmol/L) & $0.92 \pm 7.75$ & $0.64 \pm 9.19$ & $\mathrm{P}<0.05^{*}$ \\
Total cholesterol (mmol/L) & $3.27 \pm 0.23$ & $2.32 \pm 0.05$ & $\mathrm{P}<0.05^{*}$ \\
LDL-cholesterol (mmol/L) & $1.74 \pm 0.043$ & $0.86 \pm 0.05$ & $\mathrm{P}<0.001^{*}$ \\
HDL-cholesterol (mmol/L) & $1.02 \pm 0.06$ & $1.9 \pm 0.05$ & $\mathrm{P}<0.001^{*}$ \\
VLDL-cholesterol (mmol/L) & $0.79 \pm 0.01$ & $0.36 \pm 0.01$ & $\mathrm{P}<0.001^{*}$ \\
\hline
\end{tabular}

difference was found in CAT enzyme activity between the two groups, $(\mathrm{p}>0.05)$ (Table 2).

The present study also showed significant increase heart tissues level of MDA and PCO in obese animals than the control. There was significant decrease in heart GST, GPx, and PON 1 enzymes activities, with no significant difference in CAT enzyme activity in obese rats, ( $p>0.05$ ). GSH heart tissues level showed a significant increase in obese animals (Table 3).

Table 4 showed significant increase of renal tissue levels of MDA and PCO in obese rats as compared to the control group. Also there was a significant decrease in the activities of renal GST, GPx, CAT and PON 1 enzymes in obese rats. GSH level showed a significant decrease in obese rats than the control.

The correlation matrix in our study showed that in obese animals there was a negative correlation between MDA and PCO levels and the activities of GPx, GST and PON1 in the hepatic, heart and renal tissues and with CAT enzyme activity in renal tissues. No correlation was detected between MDA or PCO tissue levels and CAT enzyme activity in the hepatic and heart tissues. A negative correlation was detected between MDA, PCO levels and GSH levels in both hepatic and renal tissues. Positive correlation was found between heart MDA and PCO levels and the GSH level (Tables $5,6,7)$.

\section{Discussion}

Obesity is a strong risk factor for developing dyslipidemia [30,31], diabetes mellitus [32], fatty liver (which can later progress to nonalcoholic fatty liver disease [33], cardiovascular $(\mathrm{CV})$ diseases such as heart failure (HF) and coronary heart disease (CHD) [15].

Feeding of (HFD) to rats was proved to be a useful model of putative effects of dietary fat in humans [34]. Rat models are therefore useful tools for inducing obesity as they will readily gain weight when fed high-fat diets [2].

In the present study, obesity was induced in white albino rats by using a high fat diet formula. Obesity was induced in 16 weeks. The weight gained by rats fed HFD formula, was significantly more than that gained by those fed the normal diet. Many workers were able to induce obesity in rats using different formulas of high fat diets [16,35-38]. The response of animals to the HFD is a subtle but cumulative effect, because it took over a 10 weeks period. The difference in weight gain in all above studies may be due to age, genetic makeup of the different strains and composition of different formulas [35,36].

HDF resulted in dyslipidemic changes as illustrated by increasing serum levels of triacylglyceral, total cholesterol, LDL-cholesterol and VLDL-cholesterol and low level of HDL cholesterol as compared with control; a finding in accordance with that of Woo et al [39], and Kamal and mohamed [40]. Dyslipidemic changes occurs in obesity may be due to the increased triacylglycerol, content of the liver due to increased influx of excess NEFAs into the liver[41]. It has been revealed that altered lipid concentrations and qualitative changes of the lipoprotein fractions in obesity are associated with an increased risk of various adverse effects of obesity $[42,43]$. Additionally, lipid alterations have been considered as contributory factors to oxidative stress in obesity [44]. Increased production of reactive oxygen species as well as reduced antioxidant defense mechanisms have been suggested to play a role in both humans and animal models of obesity $[3,45]$.

Lipid peroxidation is thought to be a component of obesity-induced pathology [46]. The data presented in this study showed that obesity increased lipid peroxidation in hepatic, cardiac and renal tissues as expressed by increased tissue levels of MDA.

Table 2 Statistical comparison between all studied parameters in liver tissues.

\begin{tabular}{|c|c|c|c|}
\hline Parameter & $\begin{array}{l}\text { Group I } \\
(n=30)\end{array}$ & $\begin{array}{l}\text { Group II } \\
(n=30)\end{array}$ & $\mathbf{P}$ \\
\hline MDA (nmol/g wet tissue) & $93.30 \pm 9.63$ & $21.7 \pm 5.66$ & $P<0.05^{*}$ \\
\hline Protein carbonyl (nmol/g wet tissue) & $26.44 \pm 2.32$ & $20.16 \pm 1.13$ & $P<0.05^{*}$ \\
\hline GSH (mg/g/g wet tissue) & $93.32 \pm 9.62$ & $124.24 \pm 1.39$ & $P<0.05^{*}$ \\
\hline GST ( $\mu \mathrm{mol} / \mathrm{g}$ wet tissue) & $343.7 \pm 21.36$ & $470.9 \pm 22.9$ & $P<0.05^{*}$ \\
\hline GPx (IU/g wet tissue) & $21.85 \pm 2.68$ & $29.14 \pm 1.76$ & $P<0.05^{*}$ \\
\hline CAT ( $\mu \mathrm{mol} \mathrm{H} 2 \mathrm{O} 2$ consumed/mg protein/min) & $664.26 \pm 6.66$ & $665.80 \pm 6.77$ & $P>0.05$ \\
\hline PON 1 (U/mg protein/min) & $151.833 \pm 61.55$ & $284.31 \pm 110.60$ & $P<0.05^{*}$ \\
\hline
\end{tabular}


Table 3 Statistical comparison between all studied parameters in the heart tissues.

\begin{tabular}{lccc}
\hline Parameter & $\begin{array}{c}\text { Group I } \\
(\boldsymbol{n}=\mathbf{3 0})\end{array}$ & $\begin{array}{l}\text { Group II } \\
(\boldsymbol{n}=\mathbf{3 0})\end{array}$ & P \\
\hline MDA (nmol/g wet tissue) & $29.38 \pm 4.75$ & $48.99 \pm 4.40$ & $P<0.05^{*}$ \\
Protein carbonyl (nmol/g wet tissue) & $18.4 \pm 1.95$ & $22.86 \pm 2.95$ & $P<0.05^{*}$ \\
GSH (mg/g/g wet tissue) & $90.54 \pm 5.59$ & $98.2 \pm 3.67$ & $P<0.05^{*}$ \\
GST ( $\boldsymbol{M m o l} / \mathbf{g}$ wet tissue) & $289.6 \pm 16.95$ & $261.158 \pm 62.09$ & $\mathrm{P}<0.05^{*}$ \\
GPX (IU/g wet tissue) & $26.1 \pm 2.06$ & $20.9 \pm 2.06$ & $\mathrm{P}<0.05^{*}$ \\
CAT ( $\boldsymbol{\mu m o l ~ H 2 O 2 ~ c o n s u m e d / m g ~ p r o t e i n / m i n ) ~}$ & $591.8 \pm 4.75$ & $586.5 \pm 9.5$ & $P>0.05$ \\
PON $\mathbf{1}(\mathbf{U} / \mathbf{m g}$ protein/min) & $188.54 \pm 58.62$ & $115.74 \pm 30.26$ & $P<0.05^{*}$ \\
\hline
\end{tabular}

Our results are in basic agreement with the results of Vincent, et al., [47], Olusi et al., [8], and Amirkhizi et al., [46] who showed that, obesity is an independent risk factor for increasing lipid peroxidation and decreased activity of cytoprotective enzymes. Obesity can cause increased lipid peroxidation by progressive and cumulative cell injury resulting from pressure of the large body mass. Cell injury causes the release of cytokines, especially tumor necrosis factor alpha (TNF- $\alpha$ ) which generates ROS from the tissues which in turn cause lipid peroxidation [48]. The hypertriglyceridemia seen in obese rats may contribute to the alteration in the oxidant-antioxidant balance, suggesting that an increase in the bioavailability of free fatty acids can increase lipid peroxidation [46].

Cellular proteins are believed to be the target of free radical-induced oxidative injury. Protein carbonyl (PCO) content of liver, heart and kidney is increased significantly in obese rats compared to normal rats. Increasing PCO in obesity may be due to damage of cellular proteins by ROS generated in obesity. The accumulation of oxidized proteins might impair the cell function. The use of $\mathrm{PCO}$ as a marker for measuring of damaged proteins may have some advantages over other markers, because of relatively early formation, greater stability and reliability and also their longer life-span [49].

There are several potential mechanisms for of the increasing lipid peroxidation and protein carbonyl in hepatic, cardiac and renal tissues. Reactive oxygen species (ROS) and lipid peroxidation products impaired the respiratory chain in hepatocytes either directly or indirectly through oxidative damage to the mitochondrial genome. These features, in turn, lead to the generation of more ROS, and a vicious cycle ensues. Mitochondrial dysfunction can also lead to apoptosis or necrosis depending on the energy status of the cell. Finally, ROS and lipid peroxidation products also activate stellate cells, thus resulting in fibrosis [50,51].

Lipid peroxidation in the heart leads to loss of the cellular membrane integrity due to oxidative modification of lipids and proteins that can ultimately lead to cardiac arrhythmias, poor contractility, infarction, cardiac failure or sudden death [47]. The potential mechanism for increased lipid peroxidation in cardiac tissue may be due increased lipid substrate within the myocardium in which can serve as a larger target for oxidation by free radicals $[47,52]$. It is well established that elevated myocardial work and mechanical overload is associated with increased free radical production consequently lipid peroxidation [53]. Mechanical overload-induced increases in muscle oxygen consumption accelerate electron flux through the mitochondria in proportion to the need for ATP. This results in increased electron leakage from the electron transport chain and increased production of superoxide anions [47].

Several mechanisms may contribute to the onset and/ or the progression of renal involvement in experimental obesity among them; lipid peroxidation and oxidative stress have been frequently proposed. HFD induces alteration of renal lipid metabolism by an imbalance between lipogenesis and lipolysis in the kidney, as well as systemic metabolic abnormalities and subsequent

Table 4 Statistical comparison between all studied parameters in the kidney tissues.

\begin{tabular}{|c|c|c|c|}
\hline Parameter & $\begin{array}{l}\text { Group I } \\
(n=30)\end{array}$ & $\begin{array}{l}\text { Group II } \\
(n=30)\end{array}$ & $\mathbf{P}$ \\
\hline MDA (nmol/g wet tissue) & $69.09 \pm 6.43$ & $41.32 \pm 4.79$ & $P<0.001^{*}$ \\
\hline Protein carbonyl (nmol/g wet tissue) & $26.54 \pm 3.4$ & $18.86 \pm 1.69$ & $P<0.001^{*}$ \\
\hline GSH (mg/g wet tissue) & $89.89 \pm 1.9$ & $101 \pm 2.38$ & $P<0.001^{*}$ \\
\hline GST ( $\mu \mathrm{mol} / \mathrm{g}$ wet tissue) & $223.97 \pm 10.459$ & $258.76 \pm 16.6$ & $P<0.001^{*}$ \\
\hline GPx (IU/g wet tissue) & $20.94 \pm 2.85$ & $28.55 \pm 4.779$ & $P<0.001^{*}$ \\
\hline CAT ( $\mu \mathrm{mol} \mathrm{H} 2 \mathrm{O} 2$ consumed $/ \mathrm{mg} /$ protein $/ \mathrm{min}$ ) & $577.37 \pm 7.69$ & $585.9 \pm 3.7$ & $P<0.001^{*}$ \\
\hline PON 1 (U/mg protein/min) & $93.23 \pm 12.45$ & $112.43 \pm 15.32$ & $P<0.001^{*}$ \\
\hline
\end{tabular}


Table 5 Correlation matrix between MDA, PCO levels and the studied antioxidants in liver tissues.

\begin{tabular}{ccccccc}
\hline & & GSH & GST & GPx & CAT & PON1 \\
\hline MDA & $r$ & -0.642 & -0.423 & -0.796 & -0.325 & -0.652 \\
& P-value & 0.002 & $0.008^{*}$ & $0.001^{*}$ & 0.475 & $0.025^{*}$ \\
\hline PCO & $r$ & 0.410 & -0.685 & -0.586 & 0.319 & -0.420 \\
& P-value & $0.001^{*}$ & $0.001^{*}$ & $0.017^{*}$ & 0.112 & $0.039^{*}$ \\
\hline
\end{tabular}

renal lipid accumulation and lipid peroxidation leading to renal injury [54]. The accumulation of adipose tissue around the kidneys of obese rats penetrates into the medullary sinuses thus increased intrarenal pressures which may cause damage the renal tissue. Damaged renal tissue acts as sources of ROS and develops lipid peroxidation. An increased lipid peroxidation in the kidney tissue, as well as modification of the circulating LDL/VLDL fraction, is probably involved in the onset of kidney lesions in this normoglycaemic rodent model of obesity [55].

It has been shown that animal body had an effective mechanism to prevent the free radical induced tissue cell damage, this accomplished by a set of endogenous antioxidant enzymes and protein such as GST, SOD, CAT, GPX, GRD and GSH. When the balance between ROS production and antioxidant defense is lost oxidative stress results; which through a serious of events deregulates the cellular functions leading various pathological conditions [10]. GST, CAT and GPX constituted a mutually supportive team of defense against reactive oxygen species. In the present study GST, CAT, GPX and PON 1 enzymes activity and GSH protein were measured in hepatic, cardiac and renal tissue and the data showed clearly a significant decrease in the activities of GST, GPx and PON 1 enzymes in liver, heart and renal tissues in obese rats as compared to the control group. Catalase (CAT) enzyme showed a non significant change in hepatic and heart tissues and decreased in renal tissues of obese rats. GSH level showed significant decrease in both liver and renal tissues in obese rats. While its level in heart tissues showed significant increase in obese rats. Our results were in agreement with many authors $[[8,47,50]$ and [55]]. There are several mechanisms explaining the reduction of antioxidant enzymes in obese rats;

Table 6 Correlation matrix between MDA, PCO levels and the studied antioxidants in heart tissues.

\begin{tabular}{ccccccc}
\hline & & GSH & GST & GPx & CAT & PON1 \\
\hline MDA & $r$ & 0.597 & -0.841 & -0.684 & -0.201 & -0.583 \\
& P-value & $0.042^{*}$ & $0.041^{*}$ & $0.021^{*}$ & 0.523 & $0.030^{*}$ \\
\hline \multirow{2}{*}{ PCO } & $r$ & 0.410 & 0.685 & 0.586 & 0.355 & -0.523 \\
& P-value & $0.001^{*}$ & $0.001^{*}$ & $0.017^{*}$ & 0.099 & $0.022^{*}$ \\
\hline
\end{tabular}

Table 7 Correlation matrix between MDA, PCO levels and the studied antioxidants in kidney tissues.

\begin{tabular}{ccccccc}
\hline & & GSH & GST & GPx & CAT & PON1 \\
\hline MDA & $r$ & -0.538 & -0.417 & -0.745 & -0.492 & -0.639 \\
& P-value & $0.022^{*}$ & $0.028^{*}$ & $0.044^{*}$ & $0.020^{*}$ & $0.011^{*}$ \\
\hline PCO & $r$ & 0.410 & 0.685 & 0.586 & 0.458 & -0.752 \\
& P-value & $0.001^{*}$ & $0.001^{*}$ & $0.017^{*}$ & $0.007^{*}$ & $0.009^{*}$ \\
\hline
\end{tabular}

The increased lipid peroxidation lead to inactivation of the enzymes by crosses linking with MDA; this will cause an increased accumulation of superoxide, $\mathrm{H}_{2} \mathrm{O}_{2}$ and hydroxyl radicals which could further stimulate lipid peroxidation. This mechanism has a clue from work of Demori et al., (2006) [56] and Moyà et al., 2008 [50] who showed that the liver catalase, glutathione peroxidase, and $\mathrm{Mn}$-superoxide dismutase were reduced in response to the cafeteria-diet feeding in obese rats. Furthermore our correlation study indicated that there is negative correlation between MDA and PCO levels and enzymes activities of GPx, GST and PON 1 in the liver, heart and renal tissues and with CAT enzyme activity in kidney. This correlation finding conformed and supported the concept of inactivation of antioxidant enzymes and proteins by high level of lipid peroxidation in obesity.

Decrease of antioxidant enzyme may be due to rapid consumption and exhaustion of storage of this enzyme in fighting free radicals generated during development of obesity.

PON-1 activity could be decreased as consequence of an altered synthesis and/or secretion of HDL secondary to impaired lecithin cholesterol acyl transferase (LCAT) activity.

Under oxidative stress, PON-1 may be inactivated by Sglutathionylation a redox regulatory mechanism characterized by the formation of mixed disulfide between a protein thiol and oxidized glutathione [57].

In the present study, the non significant change in the CAT enzyme activity in liver and heart tissues of obese rat may be due to increases oxygen consumption of previous tissues due to obesity and the change of CAT enzyme activity is dependent on oxygen consumption $[12,47]$. As stated above, cardiac tissue of obese rats showed significant high content of GSH compared to normal rats. Vincent1, et al., demonstrated similar results. Increasing of GSH concentration in cardiac tissue in obese rats in response to free radical formation in an effort to protect cells against oxidative damage [47]. The adaptation of the primary antioxidant defense in the hearts of high-fat-fed animals appeared to be less complete, as indicated by the failure of other antioxidant enzyme activities including GST, GPX and PON 1 to increase in the hearts of animals on the high-fat diet. 
Non significant correlation was detected between MDA or PCO levels and CAT enzyme activity in the liver and heart tissues.

\section{Conclusion}

High fat diet-induced obesity is accompanied by increased hepatic, heart, and renal tissues oxidative stress, which is characterized by reduction in the antioxidant enzymes activities and glutathione levels, that correlate with the increase in MDA and PCO levels in most tissues. This may probably contribute to the additional progression of obesity related problems.

\section{Authors' contributions}

$\mathrm{HEH}$ and $\mathrm{AAB}$ participated in animal preparation, sample collection, and biochemical assays, and together with SAN participated in the design of the study, performed statistical analysis, and drafted the manuscript. All authors read and approved the final manuscript.

\section{Competing interests}

The authors declare that they have no competing interests.

Received: 22 December 2010 Accepted: 3 August 2011

Published: 3 August 2011

\section{References}

1. Haslam W, James P: "Obesity". Lancet 2005, 366:1197-1197.

2. Diemen $\mathrm{V}$, Trindade $\mathrm{N}$, Trindade R: Experimental model to induce obesity in rats. Acta Cir Bras 2006, 21:425-425.

3. Sonta $T$, Inoguchi $T$, Tsubouchi $H$, Sekiguchi N, Kobayashi K, Matsumoto S, Utsumi $H$, Nawata $H$ : Evidence for contribution of vascular $N A D(P) H$ oxidase to increased oxidative stress in animal models of diabetes and obesity. Free Radic Biol Med 2004, 37:115-115.

4. Furukawa S, Fujita T, Shimabukuro M, Iwaki M, Nakajima Y, Nakayama O, Makishima M, Matsuda M, Shimomura I: Increased oxidative stress in obesity and its impact on metabolic syndrome. J Clin Investig 2004, 114:1752-1761.

5. Reaven G, Abbasi F, McLaughlin T: Obesity, insulin resistance, and cardiovascular disease. Recent Prog Horm Res 2004, 59:207-207.

6. Valdecantos $P$, Matute $P$, Martínez A: Obesity and oxidative: role of antioxidants supplementation. Rev Invest Clin 2009, 61:127-127.

7. Mishra KP: Cell membrane oxidative damage induced by gammaradiation and apoptotic sensitivity. J Environ Pathol Toxicol Oncol 2004 23:61-66.

8. Olusi SO: Obesity is an independent risk factor for plasma lipid peroxidation and depletion of erythrocyte cytoprotecticve enzymes in humans. Int J Obes 2002, 26:1159-1159.

9. Uzun H, Konukoglu D, Gelisgen R, Zengin K, Taskin M: Plasma protein carbonyl and thiol stress before and after laparoscopic gastric banding in morbidly obese patients. Obes Surg 2007, 17(10):1367-1373.

10. Blokhina O, Virolainen E, Fagerstedt KV: Antioxidants, Oxidative Damage and Oxygen Deprivation Stress a Review. Ann Bot 2002, 91:179-179.

11. Sentí M, Tomás M, Fitó M, Weinbrenner T, Covas M, Sala J, Masiá R, Marrugat J: Antioxidant paraoxonase 1 activity in the metabolic syndrome. J Clin Endocrinol \& Metab 2003, 88:5422-5426.

12. Vincent HK, Taylor AG: Biomarkers and potential mechanisms of obesityinduced oxidant stress in humans. Int J Obes 2006, 30:400-400.

13. Xavier Pi-Sunyer F: The obesity epidemic: pathophysiology and consequences of obesity. Obes Res 2002, 10:97S-104S

14. Musaad S, Haynes EN: Biomarkers of obesity and subsequent cardiovascular events. Epidemiol Rev 2007, 29:98-114.

15. Lavie CJ, Artham SM, Milani RV, Ventura HO: The obesity paradox: impact of obesity on the prevalence prognosis of cardiovascular diseases. Postgrad Med 2008, 120:34-34.
16. Kim JH, Hahm DH, Yang DC, Kim JH, Lee HJ, Shim I: Effect of crude saponin of Korean red ginseng on high-fat diet-induced obesity in the rat. J Pharmacol Sci 2005, 97:124-124.

17. Deeg R, Ziegenohrm J: Kinetic enzymatic method for automated determination of total cholesterol in serum. Clin Chem 1983. 29(10):1798-1802.

18. Fossati P, Prencipe L: Serum triglycerides determined colourmetrically with an enzyme that produces hydrogen peroxide. Clin Chem 1982 28(1):2077-2080.

19. Friede WT, Levy RT, Fredrickson DF: Estimation of the concentration of Low Density Lipoprotein Cholesterol in plasma without use of the preparation ultra centrifuge. Ann Chem 1972, 18:499-499.

20. Burestin M, Selvenick HR, Morfin R: Rapid method for the isolation of lipoproteins from human serum by precipitation with polyanions. Lipid Res 1970, 11:583-583.

21. Rosebrough NJ, Farr AL, Randall RJ: Protein measurement with the Folin phenol reagent. J Biol Chem 1951, 193:265-275.

22. Ohkawa $\mathrm{H}$, Ohishi $\mathrm{N}$, Yagi $\mathrm{K}$ : Assay for lipid peroxides in animal tissues by thiobarbituric acid reaction. Anal Biochem 1979, 95:351-351.

23. Levine R, Garland D, Oliver C: Determination of carbonyl content of oxidatively modified proteins. Methods Enzymal 1990, 186:464-464.

24. Reznick AZ, Packer L: Oxidative damage to proteins: spectrophotometric method for carbonyl assay. Methods Enzymol 1994, 233:357-357.

25. Tietez F: Enzymic method for quantitative determination of nanogram amounts of total and oxidized glutathione: applications to mammalian blood and other tissues. Anal Biochem 1969, 27:502-502

26. Habig WH, Pabst MJ, Jacob WB: Glutathione S-transferase, the first enzymatic step in mercapturic acid formation. J Biol Chem 1974, 249:7130-7139.

27. Chiu DT, Stults FH, Tappel AL: Purification and properties of rat lung soluble glutathione peroxidase. Biochim Biophys Act 1976, 445:558-558.

28. Sinha KA: Colorimetric assay of catalase. Anal Biochem 1972, 47:389-389.

29. McElveen J, Mackness Ml, Colley CM, Peard T, Warner S, Walker CH: Distribution of Paraoxon Hydrolytic Activity in the Serum of Patients after Myocardial Infarction. Clin Chem 1986, 32:671-671.

30. Montani JP, Carroll JF, Dwyer TM, Antic V, Yang Z, Dulloo AG: Ectopic fat storage in heart, blood vessels and kidneys in the pathogenesis of cardiovascular diseases. Int J Obes 2004, 28:S58-S65.

31. Fried M, Hainer V, Basdevant A, Buchwald H, Dietel M, Finer N, Greve JW, Horber F, Mathus-Vliegen E, Scopinaro N, Steffen R, Weiner R, Widhalm K: Interdisciplinary European guidelines on surgery for severe obesity. Rozh/ Chir 2008, 87:468-468.

32. Pagotto U, Vanuzzo D, Vicennati V, Pasquali RG: Pharmacological therapy of obesity. G Ital Cardiol (Rome) 2008, 9(4 Suppl1):835-935

33. Marović D: Elevated body mass index fatty liver. Srp Arh Celok Lek 2008, 136:122-125.

34. Lopez IP, Marti A, Milagro Fl, Zulet Md Mde L, Moreno-Aliaga MJ, Martinez A De Miguel C: DNA microarray analysis of genes differentially expressed in diet-induced (cafeteria) obese rats. Obes Res 2003, 11:188-188.

35. Diniz YS, Faine LA, Galhardi CM, Rodrigues HG, Ebaid GX, Burneiko RC, Cicogna AC, Novelli EL: Monosodium glutamate in standard and highfiber diets. Metabolic syndrome and oxidative stress in rats. Nutrition 2005, 21:749-749.

36. Buettner R, Parhofer KG, Woenckhaus M, Wrede CE, Kunz-Schughart LA Scholmerich J, Bollheimer LC: Defining high-fat-diet rat models: metabolic and molecular effects of different fat types. J Mol Endocrinol 2006, 36:485-485.

37. Milagro Fl, Campión J, Martínez AJ: Weight Gain Induced by High-Fat Feeding Involves Increased Liver Oxidative Stress. Obesity 2006 14:1118-1118.

38. Mercer1 JG, Archer ZA: Diet-induced obesity in the Sprague-Dawley rat: dietary manipulations and their effect on hypothalamic neuropeptide energy balance systems. Biochem Soc Transact 2005, 33:1086-1086.

39. Woo MN, Bok SH, Lee MK, Kim HJ, Jeon SM, Do GM, Shin SK, Ha TY, Choi MS: Anti-obesity hypolipidemic effects of a proprietary herb fiber combination (S\&S PWH) in rats fed high-fat diets. J Med Food 2008, 11:169-78

40. Kamal AA, Mohamed AN. Effect of Carnitine and herbal mixture extract on obesity induced by high fat diet in rats. Diabet \& Metab Synd 2009, 1:1-17. 
41. Grundy SM: Metabolic complications of obesity. Obesity, Metabolic Syndrome, and Cardiovascular Disease. J Clin Endo \& Metab 2004, 89(6):2595-2600

42. Després JP, Lemieux I, Bergeron J, Pibarot P, Mathieu P, Larose E, RodésCabau J, Bertrand O, Poirier P: Abdominal obesity and the metabolic syndrome: contribution to global cardio metabolic risk. Arterioscler Thromb Vasc Biol 2008, 28:1039-1039.

43. Satoh N, Wada H, Ono K, Yamakage H, Yamada K, Nakano T, Hattori M, Shimatsu A, Kuzuya H, Hasegawa K: Small dense LDL-cholesterol relative to LDL-cholesterol is a strong independent determinant of hypoadiponectinemi a in metabolic syndrome. Circ J 2008, 72:932-939.

44. Leopold JA, Loscalzo J: Oxidative mechanisms and athero-thrombotic cardiovascular disease. Drug Discov 2008, 5:5-5.

45. Keaney JF, Larson MG, Vasan RS, Wilson PWF, Lipinska I, Corey D, et al: Obesity and systemic oxidative stress: clinical correlates of oxidative stress in the Framingham study. Arterioscler Thromb Vasc Biol 2003, 23:434-434.

46. Amirkhizi F, Siassi F, Minaie S, Djalali M, Rahimi A, Chamari M: Is obesity associated with increased plasma lipid peroxidation and oxidative stress in women. ARYA Atherosclerosis Journal 2007, 2(4):189-192.

47. Vincent HK, Powers SK, Dirks AJ, Scarpace P: Mechanism for obesityinduced increase in myocardial lipid per-oxidation. Int J Obes 2001, 25:378-378.

48. Lachieitner M, Koch T, Harold M, Dzien A, Hoppiahler F: Tumour necrosis factor-alpha plasma level in patients with type 1 diabetes mellitus and its association with glycaemic control and cardiovascular risk factors. $J$ Intern Med 2000, 248:67-67.

49. Hafize U, Dildar K, Remisa G, Kagan Z, Mustafa T: Plasma Protein Carbonyl and Thiol Stress Before and After Laparoscopic Gastric Banding in Morbidly Obese Patients. Obesity Surgery 2007, 17(10):1367-1373.

50. Moya ET, Perez YG, Fiol M, Magdalena Gianotti M, Lladó I, Ana Proenza AM: Gender related differences in paraoxonase 1 response to high-fat dietinduced oxidative stress. Obesity 2008, 16(10):2232-2238.

51. Carmiel-Haggai M, Nieto N: A high-fat diet leads to the progression of non-alcoholic fatty liver disease in obese rats. FASEB J 2005, 19:136-136.

52. Esterbauer $\mathrm{H}$, Gebicki J, Puhl $\mathrm{H}$, Jurgens $\mathrm{G}$ : The role of lipid peroxidation and antioxidants in oxidative modification of LDL. Free Radical Biol Med 1992, 13:341-341.

53. Ji LL: Exercise and oxidative stress: role of the cellular antioxidant systems. Exercise Sport Sci Rev 1995, 23:135-166.

54. Kume S, Uzu T, Araki S, Sugimoto T, Isshiki K, Kanasaki M, Sakaguchi M, Kubota N, Terauchi Y, Kadowaki T, Haneda M, Kashiwagi A, Koya D: Role of Altered Renal Lipid Metabolism in the Development of Renal Injury Induced by a High-Fat Diet. J Am Soc Nephrol 2007, 18:2715-2715.

55. Lannaud-Bournoville M, Conti M, Bazin R, Michel O, Bariéty J, Chevalier J, Myara I: Oxidative stress occurs in absence of hyperglycaemia and inflammation in the onset of kidney lesions in normotensive obese rats. Nephrol Dial Transplant 1999, 15(4):467-476.

56. Demori I, Voci A, Fugassa E, Burlando B: Combined effects of high-fat diet and ethanol induce oxidative stress in rat liver. Alcohol 2006, 40:185-185.

57. Rozenberg O, Aviram M: Glutathionylation regulates HDL-associated paraoxonase 1 (PON1) activity. Biochem Biophys Res Commun 2006 351(2):492-498.

\section{doi:10.1186/1758-5996-3-17}

Cite this article as: Noeman et al:: Biochemical Study of Oxidative Stress Markers in the Liver, Kidney and Heart of High Fat Diet Induced Obesity in Rats. Diabetology \& Metabolic Syndrome 2011 3:17.

\section{Submit your next manuscript to BioMed Central and take full advantage of:}

- Convenient online submission

- Thorough peer review

- No space constraints or color figure charges

- Immediate publication on acceptance

- Inclusion in PubMed, CAS, Scopus and Google Scholar

- Research which is freely available for redistribution

Submit your manuscript at www.biomedcentral.com/submit 